\title{
Adsorption of Lactic Acid from Fermentation Broth and Aqueous Solutions on Zeolite Molecular Sieves
}

\author{
Isam $\mathrm{H}$. Aljundi \\ Mutah University \\ Joanne M. Belovich \\ Equlvelathissagteaghlitiersily works at: https://engagedscholarship.csuohio.edu/encbe_facpub \\ Partof the Membrane Science Commons \\ Orhan Talu

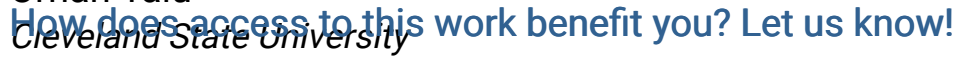 \\ Publisher's Statement
}

NOTICE: this is the author's version of a work that was accepted for publication in Chemical Engineering Science. Changes resulting from the publishing process, such as peer review, editing, corrections, structural formatting, and other quality control mechanisms may not be reflected in this document. Changes may have been made to this work since it was submitted for publication. A definitive version was subsequently published in Chemical Engineering Science, [VOL 60, ISSUE 18, (September 2005)] DOI 10.1016/j.ces.2005.04.034

\section{Original Citation}

Aljundi, I. H., Belovich, J. M., , \& Talu, O. (2005). Adsorption of lactic acid from fermentation broth and aqueous solutions on Zeolite molecular sieves. Chemical Engineering Science, 60(18), 5004-5009. doi:10.1016/j.ces.2005.04.034

\section{Repository Citation}

Aljundi, Isam H.; Belovich, Joanne M.; and Talu, Orhan, "Adsorption of Lactic Acid from Fermentation Broth and Aqueous Solutions on Zeolite Molecular Sieves" (2005). Chemical \& Biomedical Engineering Faculty Publications. 68.

https://engagedscholarship.csuohio.edu/encbe_facpub/68

This Article is brought to you for free and open access by the Chemical \& Biomedical Engineering Department at EngagedScholarship@CSU. It has been accepted for inclusion in Chemical \& Biomedical Engineering Faculty Publications by an authorized administrator of EngagedScholarship@CSU. For more information, please contact library.es@csuohio.edu. 


\title{
Adsorption of lactic acid from fermentation broth and aqueous solutions on Zeolite molecular sieves
}

\author{
Isam H. Aljundi ${ }^{\mathrm{a}, *}$, Joanne M. Belovich ${ }^{\mathrm{b}}$, Orhan Talu ${ }^{\mathrm{b}}$ \\ ${ }^{a}$ Chemical Engineering Department, Mutah University, Al-Karak 61710, Jordan \\ ${ }^{\mathrm{b}}$ Chemical Engineering Department, Cleveland State University, Cleveland, OH 44102, USA
}

\section{Introduction}

The continuous decrease in crude oil resources makes the production of chemicals from renewable resources an eventual necessity. Limitations in available landfill space indicate the need for greater use of biodegradable materials in single-use products. The future of the plastic industry depends on its ability to synthesize biodegradable polymers of the required strength and durability.

The polymer material polylactic acid (PLA) meets both the needs for renewable resource and biodegradability. Dow Chemical and Cargill have the largest polylactide producing company with an annual capacity of 140,000 ton located in Blair, USA.

PLA is used extensively for the design of drug delivery systems for peptides and vaccines, for the manufacture of medical devices and wound dressings, as well as for fabricating scaffolds in tissue engineering (Langer and Vacanti, 1993). Moreover, the polymer can be formulated with a variety of desirable physical properties and degradation rates, making it extremely versatile. PLA is traditionally manufactured in a three-phase process: (1) fermentation by various strains of Lactobacillus to produce lactic acid; (2) recovery of lactic acid from the fermentation broth, and (3) polymerization of the lactic acid.

The cost of lactic acid (the raw material of PLA) is mainly due to the downstream processing costs rather than its synthesis costs. The major limitation of lactic acid fermentation is that lactic acid secretion by Lactobacillus is inhibited by both the presence of the lactic acid in the fermentation broth, and the associated drop in $\mathrm{pH}$ (Goksungur and Guvenc, 1997; Shimizu et al., 1996b). Undissociated lactic acid acts as an inhibitor for growth and lactic acid production by diffusing through the membrane and decreasing intracellular $\mathrm{pH}$. 
Solutions to these difficulties may be found in processes that use in situ removal of the acid product from the broth during fermentation (Sun et al., 1999). Methods investigated have included extraction, electrodialysis, ion exchange and adsorption on activated carbon, each with their own limitations.

Solvent extraction has been used for the purification of carboxylic acid such as lactic acid and succinic acid (Scholler et al., 1993; Hano et al., 1992-1993; Martin et al., 1992). But these solvents in situ are toxic as they rupture the cell membrane causing the metabolite to leak out. The toxicity of organic solvents was always a problem (Martak et al., 1997; Shimizu et al., 1996a). Although it can be overcome by immobilizing the cells (Yabannavar and Wang, 1991), it remains a problem if the cells are directly exposed to the extractant.

Electrodialysis has been used as a technique for the isolation and purification of lactic acid from fermentation media (Vonktaveesuk et al., 1994; Sato and Mijaki, 1988; Czytko et al., 1987). Since other anions also go with lactic acid and other broth components end up in the product stream by diffusion, further processing is necessary to remove these impurities. The cost of building an electrodialysis unit for largescale operation is not economically feasible (Evangelista, 1994).

The sorption of carboxylic acids on ion exchange resins has also been studied (Tung, 1993; Kabawata et al., 1981). The major drawback of the ion exchange method is that the fermentation broth contains other anions $\left(\mathrm{SO}_{4}^{2-}, \mathrm{Cl}^{-}\right)$in addition to lactate, which compete with the acidic sites on the ion exchange material. Furthermore, these anions must be replenished, as some are necessary for the fermentation. This method also requires the use of additional chemicals (salt solutions) to recover the acid from the resin.

$\mathrm{Ju}$ and Chen (1998) examined the activated carbon in lactic acid fermentation from glucose using Lactobacillus delbrueckii. The cells were also rapidly adsorbed on activated carbon, which will limit its application in lactic acid fermentation. The problem originates from the structure of such materials, which has a wide pore size distribution. The interior is accessible by all sizes of molecules since the pore size ranges from micrometer to angstrom level. The competition by other heavier hydrocarbons in the broth for adsorption sites will reduce the selectivity and the capacity of the activated carbon.

An alternative method of recovery of lactic acid from fermentation broth, based on adsorption on Silicalite molecular sieves, has been investigated. Silicalite pellets have pore sizes suitable for adsorption of lactic acid, yet which can exclude larger size components of the fermentation broth, such as proteins. It also has low affinity for water and it is characterized by high thermal and hydrothermal stability.

\section{Materials and methods}

A YSI biochemistry analyzer YSI-2700 (Yellow Springs Inc., $\mathrm{OH}$ ) was used in analyzing the lactic acid and glucose concentrations. The lactic acid used in all experimental work was a technical grade $\mathrm{L}(+)$ lactic acid (Aldrich Chemical Company, WI) with a label concentration of $85 \% \mathrm{w} / \mathrm{w}$. This lactic acid solution was boiled overnight in a total reflux apparatus to hydrolyze any lactic acid polymer. Fermentation broth was obtained from the anaerobic culture of L. rhamnosus grown on MRS media (Difco Inc., MI) without $\mathrm{pH}$ control. Cells were removed from the fermentation broth via ultrafiltration. After about 5 days of culture, the fermentation broth contained $16.7 \pm 1.0 \mathrm{~g} / \mathrm{L}$ lactic acid and $5.7 \pm 0.4 \mathrm{~g} / \mathrm{L}$ glucose. The broth was supplemented with the refluxed $85 \% \mathrm{w} / \mathrm{w}$ lactic acid for some of the experiments. The glucose solution used in all experimental work was a sterilized $\mathrm{D}[+]$ glucose solution (Sigma Chemical Co., MO) with a concentration of $45 \% \mathrm{w} / \mathrm{w}$. The adsorbent used in all the batch and column experiments were Silicalite pellets (UOP Molecular Sieves Co., IL).

Batch adsorption experiments were conducted by equilibrating $4 \mathrm{~g}$ Silicalite with $15 \mathrm{~mL}$ lactic acid solution or cellfree fermentation broth in $50 \mathrm{~mL}$ Erlenmeyer flasks. Flasks were kept well mixed at $24 \pm 1{ }^{\circ} \mathrm{C}$ in a shaker bath overnight at various initial lactic acid concentrations. After the adsorption experiment was completed, batch desorption experiments were performed by diluting the solution in each flask with $15 \mathrm{~mL}$ of DI-water, and equilibrating the flasks at $24 \pm 1^{\circ} \mathrm{C}$ in a shaker bath. After $24 \mathrm{~h}$, the supernatant was sampled and the lactic acid and glucose concentrations were measured.

Column adsorption experiments were conducted in an insulated brass fixed-bed column of $1.9 \mathrm{~cm}$ diameter and $25.5 \mathrm{~cm}$ length. The column was packed with $56.27 \mathrm{~g}$ of fresh Silicalite pellets. A peristaltic pump transported either broth or lactate solution to the column at an average flow rate of $3.95 \mathrm{~mL} / \mathrm{min}$. Glass wool was put on the top and bottom of the bed to obtain a good liquid distribution. The adsorption stepw as performed at $25 \pm 1{ }^{\circ} \mathrm{C}$, and then, the column was regenerated by preheating it to $95 \pm 1^{\circ} \mathrm{C}$ using heating tape, then passing steam through the bed at a flow rate of $6.5 \mathrm{~g} / \mathrm{L}$ and a temperature of $138 \pm 6^{\circ} \mathrm{C}$. Samples of the effluent condensate were collected and analyzed for lactate concentration.

Glucose breakthrough curves were measured in a similar manner, with $413 \mathrm{~mL}$ of fermentation broth with glucose concentration of $5.26 \mathrm{~g} / \mathrm{L}$ fed to the adsorption column at a flow rate of $5.82 \mathrm{~mL} / \mathrm{min}$.

The effect of temperature on batch adsorption was studied by mixing $4.0 \mathrm{~g}$ of Silicalite with $15.0 \mathrm{~mL}$ of broth and allowing the flasks to equilibrate in a shaker bath for $24 \mathrm{~h}$ at 26,52 and $66 \pm 1{ }^{\circ} \mathrm{C}$.

\section{Results and discussion}

Results from the batch adsorption and desorption experiments are shown in Tables 1 and 2 . The Silicalite adsorbed lactic acid upto $46 \mathrm{~g} / \mathrm{kg}$ in aqueous solution and upto $37 \mathrm{~g} / \mathrm{kg}$ 
Table 1

Lactic acid adsorption and desorption isotherms at $24 \pm 1{ }^{\circ} \mathrm{C}$ from aqueous solution on Silicalite

\begin{tabular}{llllll}
\hline $\begin{array}{l}\text { Experiment } \\
\text { number }\end{array}$ & $\begin{array}{l}\text { Adsorption } \\
\text { experiments }\end{array}$ & & & $\begin{array}{l}\text { Desorption } \\
\text { experiments }\end{array}$ \\
\cline { 2 - 3 } \cline { 5 - 6 } & $\begin{array}{l}\text { Equilibrium } \\
\text { concentration } \\
(\mathrm{g} / \mathrm{L})\end{array}$ & $\begin{array}{l}\text { Amount } \\
\text { adsorbed } \\
(\mathrm{g} / \mathrm{kg})\end{array}$ & & $\begin{array}{l}\text { Equilibrium } \\
\text { concentration } \\
(\mathrm{g} / \mathrm{L})\end{array}$ & $\begin{array}{l}\text { Amount } \\
\text { adsorbed } \\
(\mathrm{g} / \mathrm{kg})\end{array}$ \\
\hline 1 & 24.60 & 46.10 & 18.69 & 44.00 \\
2 & 20.44 & 32.14 & 14.00 & 33.35 \\
3 & 14.40 & 17.04 & 11.55 & 22.18 \\
4 & 11.96 & 8.13 & & 8.08 & 10.48 \\
5 & 8.08 & 4.03 & & 5.98 & 8.13 \\
6 & 4.81 & 0.35 & 4.33 & 1.87 \\
\hline
\end{tabular}

Table 2

Lactic acid adsorption and desorption isotherms at $24 \pm 1{ }^{\circ} \mathrm{C}$ from fermentation broth on Silicalite

\begin{tabular}{|c|c|c|c|c|}
\hline \multirow[t]{2}{*}{$\begin{array}{l}\text { Experiment } \\
\text { number }\end{array}$} & \multicolumn{2}{|l|}{$\begin{array}{l}\text { Adsorption } \\
\text { experiments }\end{array}$} & \multicolumn{2}{|l|}{$\begin{array}{l}\text { Desorption } \\
\text { experiments }\end{array}$} \\
\hline & $\begin{array}{l}\text { Equilibrium } \\
\text { concentration } \\
(\mathrm{g} / \mathrm{L})\end{array}$ & $\begin{array}{l}\text { Amount } \\
\text { adsorbed } \\
(\mathrm{g} / \mathrm{kg})\end{array}$ & $\begin{array}{l}\text { Equilibrium } \\
\text { concentration } \\
(\mathrm{g} / \mathrm{L})\end{array}$ & $\begin{array}{l}\text { Amount } \\
\text { adsorbed } \\
(\mathrm{g} / \mathrm{kg})\end{array}$ \\
\hline 1 & 34.75 & 37.26 & 17.60 & 37.77 \\
\hline 2 & 27.28 & 32.23 & 14.16 & 30.10 \\
\hline 3 & 21.87 & 18.72 & 11.25 & 17.76 \\
\hline 4 & 15.42 & 12.13 & 7.78 & 12.58 \\
\hline 5 & 12.20 & 7.69 & 6.32 & 6.85 \\
\hline 6 & 8.45 & 3.93 & 4.37 & 3.39 \\
\hline 7 & 4.55 & 0.411 & 2.25 & 0.90 \\
\hline
\end{tabular}

in broth. The presence of extra chemical species in the broth caused Henry's constant to decrease from $2 \pm 0.7 \mathrm{~L} / \mathrm{kg}$ for the pure solution to $1 \pm 0.5 \mathrm{~L} / \mathrm{kg}$ for the broth. This adsorptive capacity is low compared to the amount of $210 \mathrm{~g} / \mathrm{kg}$ reported for lactic acid adsorption on Amberlite IRA-35 (Kaufman et al., 1994). However, Amberlite's capacity quickly diminished $93 \%$ in subsequent loadings after three cycles because of the inability to regenerate the resin and the resins' instability at elevated temperature.

The equilibrium curves obtained from desorption from the Silicalite were lower than those obtained from adsorption. This hysteresis may be the result of the shape of the openings to the pores of the solid or of the complex phenomenon of the wetting of the solid by the adsorbate (Treybal, 1981). As shown in Table 2, the adsorption of lactic acid from fermentation broth is clearly irreversible and the hysteresis loop is even wider than that of the aqueous solution. This may be due to the presence of chemical species in the broth (nutrients necessary for bacterial growth such as yeast extract, meat extract, etc.) that alters the intermolecular forces.

Table 3 shows the breakthrough data of lactic acid from aqueous and broth solutions at $25 \pm 1{ }^{\circ} \mathrm{C}$. The difference between the data of the pure and broth solutions is consistent with the equilibrium adsorption curves obtained for the two solutions.
Table 3

Breakthrough data of lactic acid from aqueous and broth solutions

\begin{tabular}{lllll}
\hline $\begin{array}{l}\text { Aqueous } \\
\text { solution }\end{array}$ & & & $\begin{array}{l}\text { Fermentation } \\
\text { broth }\end{array}$ \\
\cline { 1 - 1 } $\begin{array}{l}\text { Volume } \\
(\mathrm{mL})\end{array}$ & $\begin{array}{l}\text { Outlet acid } \\
\text { concentration } \\
(\mathrm{g} / \mathrm{L})\end{array}$ & & $\begin{array}{l}\text { Volume } \\
(\mathrm{mL})\end{array}$ & $\begin{array}{l}\text { Outlet acid } \\
\text { concentration } \\
(\mathrm{g} / \mathrm{L})\end{array}$ \\
\hline 1 & 0.14 & & 0.20 \\
23 & 0.14 & & 1 & 0.16 \\
45 & 0.74 & & 24 & 2.77 \\
68 & 2.88 & & 72 & 8.10 \\
91 & 4.86 & 96 & 10.57 \\
122 & 7.00 & 120 & 12.13 \\
154 & 8.53 & 148 & 13.16 \\
186 & 9.79 & 225 & 13.32 \\
217 & 10.76 & 263 & 14.51 \\
254 & 11.93 & 311 & 15.23 \\
290 & 12.62 & 373 & 15.59 \\
326 & 13.18 & 411 & 16.64 \\
371 & 13.97 & 415 & 15.70 \\
403 & 14.27 & &
\end{tabular}

An important characteristic of the breakthrough data is the break point that occurs after a collection of $50 \mathrm{~mL}$ of the solution. If the adsorption process were infinitely rapid, the breakthrough curve would be a straight vertical line after the break point and most of the bed capacity would be used at that break point (Geankoplis, 1993). Under the conditions of the experiment, a finite resistance to adsorption is present and a significant mass transfer occurred after the break point. The results also indicate that the length of the bed is not large compared to the length of the mass-transfer zone. It also shows that the adsorption column was almost saturated after the breakpoint in the case of the broth while significant mass transfer was still going after the break point in the case of the pure solution.

The overall mass transfer coefficient was obtained by fitting the experimental data to the model described in details elsewhere (Aljundi, 2001). The model consists of a mass balance equation on lactic acid derived from a shell balance on a volume element of differential thickness

$$
\begin{aligned}
& \frac{\partial C}{\partial t}=-v \frac{\partial C}{\partial z}-\frac{(1-\varepsilon)}{\varepsilon} \rho_{b} \frac{\partial q}{\partial t}, \\
& \left\{\begin{array}{l}
C=0, q=0 \text { at } t=0 \text { and } L>z>0 \\
C=C_{0} \text { at } z=0 \text { and } t>0
\end{array}\right\} .
\end{aligned}
$$

A linear rate transfer equation, using the particle phase concentration difference as the driving force (LDFQ), was used to describe the rate of change in the adsorbed phase concentration. The LDFQ uses a lumped parameter, $k$, to account for the mass transfer resistances (Ruthven, 1984):

$\frac{\partial q}{\partial t}=k\left(q^{*}-q\right), \quad\{q=0$ at $t=0\}$, 
where $q^{*}$, the equilibrium value of $q$, can be represented by a linear isotherm of the form

$q^{*}=K C$.

The overall mass transfer coefficient will account for the resistance to diffuse through the fluid film around the Silicalite particle and the resistance to diffuse through the pores of Silicalite to internal adsorption sites. There are many empirical equations that correlate the mass transfer coefficient and Sherwood number to Reynolds number and Schmidt number. These recommended correlations have variation as high as $\pm 50 \%$ (Geankoplis, 1993). An empirical equation for packed beds is (McCabe et al., 1993)

$N_{\mathrm{Sh}}=1.17 N_{\mathrm{Re}}^{0.585} N_{\mathrm{Sc}}^{1 / 3}$.

The diffusivity of lactic acid is estimated from (Wilke and Chang, 1970):

$D_{v}=7.4 \times 10^{-8} \frac{\left(\varphi_{B} M_{B}\right)^{1 / 2} T}{\mu V_{A}^{0.6}}$.

The fluid-phase mass transfer coefficient, $k_{e}$, calculated using Eq. (4) and the experimental conditions described previously was $2.99 \times 10^{-3} \mathrm{~cm} / \mathrm{s}$. Letting $R_{T}=1 / \mathrm{ka}$ (the overall mass transfer resistance), $R_{e}=1 / k_{e} a$ (the fluid-phase mass transfer resistance), and $R_{S}$ (the solid-phase transfer resistance), we have $R_{T}=R_{e}+R_{s}$. The external surface area of the Silicalite particle, $a\left(\mathrm{~cm}^{2} / \mathrm{cm}^{3}\right)$, is given by $a=6(1-\varepsilon) / D_{P}$. The calculated $R_{T}$ for the broth solution was $99.0 \mathrm{~s}$ and $R_{e}=20.9 \mathrm{~s}$. Hence, external resistance is only $21 \%$ of the total resistance and the internal resistance (or the solid-phase resistance) is the dominant step in adsorption.

Lactic acid concentrations from the bed regeneration are shown in Table 4 . The average recovery of lactic acid from the amount retained in the column was $65.4 \%$ and $75 \%$, for the broth and aqueous solutions, respectively.

It is believed that by choosing a high enough temperature, the speed of desorption front can be made faster than the speed of the thermal wave. In this case, desorbed species is accumulated at the front and a high concentration peak with less tail can be expected. On the other hand, when the temperature of desorption is not high enough, desorption gradually occurs and a long tailing will be expected (Suzuki, 1989).

Glucose, the carbon and energy source for cells is the major individual component in the fermentation broth other than lactic acid. Table 5 shows the breakthrough data of glucose at $25 \pm 1{ }^{\circ} \mathrm{C}$. The amount of glucose adsorbed was so small (94 $\mathrm{mg}$ adsorbed and $23 \mathrm{mg}$ desorbed), indicating negligible adsorptive capacity of Silicalite for glucose.

The effect of glucose concentration on lactic acid adsorption was also determined as shown in Table 6. The breakthrough data did not change when the glucose concentration was increased five-fold, a clear sign that the presence of the glucose upto the studied concentration did not interfere with the adsorption of lactic acid.
Table 4

Desorption data of lactic acid from aqueous and broth solutions

\begin{tabular}{|c|c|c|c|}
\hline \multicolumn{2}{|l|}{$\begin{array}{l}\text { Aqueous } \\
\text { solution }\end{array}$} & \multicolumn{2}{|c|}{$\begin{array}{l}\text { Fermentation } \\
\text { broth }\end{array}$} \\
\hline $\begin{array}{l}\text { Volume } \\
(\mathrm{mL})\end{array}$ & $\begin{array}{l}\text { Outlet acid } \\
\text { concentration }(\mathrm{g} / \mathrm{L})\end{array}$ & $\begin{array}{l}\text { Volume } \\
(\mathrm{mL})\end{array}$ & $\begin{array}{l}\text { Outlet acid } \\
\text { concentration }(\mathrm{g} / \mathrm{L})\end{array}$ \\
\hline 1 & 2.30 & 1 & 15.41 \\
\hline 4 & 18.00 & 5 & 16.11 \\
\hline 14 & 32.04 & 10 & 18.72 \\
\hline 20.5 & 34.20 & 20 & 21.24 \\
\hline 27 & 34.02 & 30 & 19.08 \\
\hline 52 & 23.94 & 50 & 12.65 \\
\hline 77 & 15.50 & 70 & 8.44 \\
\hline 102 & 13.25 & 100 & 5.81 \\
\hline 127 & 6.28 & 127 & 3.78 \\
\hline 152 & 3.33 & 150 & 2.79 \\
\hline 177 & 1.66 & 181 & 1.53 \\
\hline 202 & 0.90 & 199 & 1.17 \\
\hline 228 & 0.52 & 222 & 0.43 \\
\hline 253 & 0.31 & 249 & 0.43 \\
\hline 303 & 0.11 & 299 & 0.61 \\
\hline 353 & 0.02 & 349 & 0.16 \\
\hline 403 & 0.00 & 399 & 0.20 \\
\hline
\end{tabular}

Table 5

Breakthrough data of glucose at $25 \pm 1{ }^{\circ} \mathrm{C}$ from fermentation broth solution

Volume (mL) $6 \begin{array}{llllllllllll}6 & 23 & 41 & 58 & 76 & 99 & 116 & 157 & 198 & 244 & 291 & 349\end{array}$ Outlet glucose $0 \begin{array}{llllllllllll}0 & 23 & 150 & 209 & 250 & 265 & 285 & 282 & 290 & 292 & 289\end{array}$ concentration

$(\mathrm{mg} / \mathrm{L})$

Table 6

Breakthrough data of lactic acid with different glucose concentrations at $25^{\circ} \mathrm{C}$

\begin{tabular}{|c|c|c|c|}
\hline \multicolumn{2}{|c|}{$\begin{array}{l}\text { Experiment A, } \\
\text { glucose conc. } \\
=5.3 \mathrm{~g} / \mathrm{L}\end{array}$} & \multicolumn{2}{|c|}{$\begin{array}{l}\text { Experiment } \mathrm{B} \text {, } \\
\text { glucose conc. } \\
=26.3 \mathrm{~g} / \mathrm{L}\end{array}$} \\
\hline $\begin{array}{l}\text { Volume } \\
(\mathrm{mL})\end{array}$ & $\begin{array}{l}\text { Outlet acid } \\
\text { concentration }(\mathrm{g} / \mathrm{L})\end{array}$ & $\begin{array}{l}\text { Volume } \\
(\mathrm{mL})\end{array}$ & $\begin{array}{l}\text { Outlet acid } \\
\text { concentration }(\mathrm{g} / \mathrm{L})\end{array}$ \\
\hline 6 & 0.13 & 21 & 0.00 \\
\hline 23 & 0.13 & 35 & 0.02 \\
\hline 41 & 1.17 & 49 & 3.19 \\
\hline 58 & 7.15 & 63 & 8.24 \\
\hline 76 & 10.21 & 85 & 11.32 \\
\hline 99 & 12.46 & 113 & 12.73 \\
\hline 157 & 14.63 & 170 & 13.73 \\
\hline 198 & 14.96 & 232 & 14.58 \\
\hline 244 & 15.25 & 303 & 14.36 \\
\hline 291 & 15.50 & 373 & 14.92 \\
\hline 349 & 15.71 & 458 & 15.82 \\
\hline 413 & 15.95 & 507 & 15.44 \\
\hline
\end{tabular}

Similar behavior was also reported by Ju and Chen (1998), where they showed that glucose did not significantly affect lactic acid adsorption on activated carbon.

Adsorption is accompanied by evolution of heat since adsorbate molecules are more stabilized on the adsorbent 
Table 7

Effect of temperature on lactic acid adsorption isotherm

\begin{tabular}{|c|c|c|c|c|c|}
\hline \multicolumn{2}{|l|}{$T=26{ }^{\circ} \mathrm{C}$} & \multicolumn{2}{|l|}{$T=52{ }^{\circ} \mathrm{C}$} & \multicolumn{2}{|l|}{$T=66^{\circ} \mathrm{C}$} \\
\hline $\begin{array}{l}\text { Aqueous phase } \\
\text { concentration } \\
(\mathrm{g} / \mathrm{L})\end{array}$ & $\begin{array}{l}\text { Solid phase } \\
\text { concentration } \\
(\mathrm{mg} / \mathrm{g})\end{array}$ & $\begin{array}{l}\text { Aqueous phase } \\
\text { concentration } \\
(\mathrm{g} / \mathrm{L})\end{array}$ & $\begin{array}{l}\text { Solid phase } \\
\text { concentration } \\
(\mathrm{mg} / \mathrm{g})\end{array}$ & $\begin{array}{l}\text { Aqueous phase } \\
\text { concentration } \\
(\mathrm{g} / \mathrm{L})\end{array}$ & $\begin{array}{l}\text { Solid phase } \\
\text { concentration } \\
(\mathrm{mg} / \mathrm{g})\end{array}$ \\
\hline 14.16 & 10.51 & 15.78 & 4.66 & 16.08 & 3.59 \\
\hline 10.64 & 4.64 & 11.53 & 1.45 & 11.90 & 0.14 \\
\hline 6.63 & 2.93 & 6.92 & 1.88 & 7.19 & 0.93 \\
\hline
\end{tabular}

surface than in the bulk phase. Since adsorption is an exothermic process, the concentration of the adsorbed material decreases with increased temperature at a given equilibrium concentration, as the lactic acid isotherms of Table 7 indicate. The temperature dependency of Henry's constant obeys the van't Hoff equation (Ruthven, 1984):

$\frac{\mathrm{d} \ln K}{\mathrm{~d} T}=\frac{\Delta H}{R T^{2}}$.

Eq. (6) can be integrated to yield $\ln K=\ln K_{o}+(-\Delta H / R T)$. A plot of $\ln K$ versus $1 / T$ will yield a straight line with a slope of $-\Delta H / R$. The heat of adsorption, calculated from the slope, was $(29 \pm 17) \mathrm{kJ} / \mathrm{mol}$.

\section{Conclusions}

Silicalite adsorbed lactic acid upto $55 \mathrm{~g} / \mathrm{kg}$ in aqueous solution and upto $37 \mathrm{~g} / \mathrm{kg}$ in broth. Its capacity was maintained and was not diminished with repetitive use in the adsorption/desorption cycle. A linear isotherm was observed for the pure solution and broth with Henry's constant estimated as $1 \pm 0.5 \mathrm{~L} / \mathrm{kg}$ for the broth and $2 \pm 0.7 \mathrm{~L} / \mathrm{kg}$ for the aqueous solution. In addition, the adsorption isotherms showed a hysteresis loopwhen tested for reversibility where it was wider in the case of the fermentation broth. The kinetics of lactic acid adsorption on Silicalite was investigated in packed column studies. The amount adsorbed from the aqueous solution was approximately $50 \%$ higher than that from the broth under the same conditions. Adsorption in the column was controlled by the diffusion in the solid phase rather than the fluid. Glucose adsorbed to Silicalite to a negligible extent, and did not interfere with lactic acid adsorption. Regeneration of the bed using steam was successful in recovering $74 \%$ of the lactic acid in the pure solution, compared to $65 \%$ in the fermentation broth.

Although the Silicalite showed lower capacity for lactic acid than other polymeric adsorbents, this process still has the advantages of simplicity in operation. With in situ adsorption of lactic acid on Silicalite during fermentation, the number of process units can be reduced compared to traditional methods, and use of additional chemicals (other than water) can be eliminated.

\section{Notation}

a external surface area of the Silicalite particle

$C \quad$ lactic acid concentration in the fluid phase

$D_{P} \quad$ diameter of the Silicalite particle

$D_{v} \quad$ diffusivity

$\Delta H \quad$ heat of adsorption

$k \quad$ mass transfer coefficient

$K \quad$ Henry's constant

$L \quad$ length of the adsorption column

$M_{B} \quad$ molecular weight of solvent

$N_{\mathrm{Re}} \quad$ Reynold's number $\left(=\rho D_{P} v / \mu\right)$

$N_{\mathrm{Sc}} \quad$ Schmidt's number $\left(=\mu / \rho D_{v}\right)$

$N_{\text {Sh }} \quad$ Sherwood's number $\left(=k_{e} D_{P} / D_{v}\right)$

$q \quad$ adsorbed-phase concentration

$q^{*} \quad$ equilibrium value of $q$

$R \quad$ gas constant

$R_{e} \quad$ fluid-phase mass transfer resistance

$R_{S} \quad$ solid-phase transfer resistance

$R_{T} \quad$ overall mass transfer resistance

$t \quad$ time

$T \quad$ temperature

$v \quad$ interstitial velocity

$V_{A} \quad$ molar volume of solute

$z \quad$ height of the column

Greet letters

$\varepsilon \quad$ porosity

$\mu \quad$ viscosity of the solution

$\rho \quad$ solution density

$\rho_{b} \quad$ bed density

$\varphi_{B} \quad$ association constant for solvent

\section{References}

Aljundi, I.H., 2001. Fermentation and separation of lactic acid. Ph.D. Dissertation, Cleveland State University.

Czytko, M., Ishii, K., Kawai, K., 1987. Continuous glucose fermentation for lactic acid production: recovery of acid by electrodialysis. ChemieIngenieur-Technik 59, 952-954.

Evangelista, R.L., 1994. Recovery and purification of lactic acid from fermentation broth by adsorption. Ph.D. Dissertation, Iowa State University. 
Geankoplis, C., 1993. Transport Processes and Unit Operations. third ed. Prentice-Hall, NJ,

Goksungur, Y., Guvenc, U., 1997. Batch and continuous production of lactic acid from beet molasses by Lactobacillus delbrueckii IFO 3202. Journal of Chemical Technology and Biotechnology 69, 399-404.

Hano, T., Matsumoto, M., Uenoyama, S., Ohtake, T., Kawano, Y., Miura, S., 1992-1993. Separation of lactic acid from fermented broth by solvent extraction. Bioseparation 3 (5), 321-326.

Ju, L., Chen, C., 1998. Adsorption characteristics of polyvinylpyridine and activated carbon for lactic acid recovery from fermentation of Lactobacillus delbrueckii. Separation Science and Technology 33 (10), 1423-1437.

Kabawata, N., Yosida, J., Tanigawa, Y., 1981. Removal and recovery of organic pollutants from aquatic environment. 4. Separation of carboxylic acids from aqueous solution using cross-linked poly(4vinylpyridine). Industrial Engineering Chemistry Process Research and Development 20 (2), 386-390.

Kaufman, E., Cooper, S., Davison, B., 1994. Screening of resins for use in a biparticle fluidized-bed bioreactor for the continuous fermentation and separation of lactic acid. Applied Biochemistry and biotechnology $45 / 46,545-553$.

Langer, R., Vacanti, J., 1993. Tissue engineering. Science 260, 920-926.

Martak, J., Sabolova, E., Schlosser, S., Rosenberg, M., Kristofikova, L., 1997. Toxity of organic solvents used in situ in fermentation of lactic acid by Rhizopus arrhizus. Biotechnology Techniques 11 (2), 71-75.

Martin, M.S., Pazos, C., Coca, J., 1992. Reactive extraction of lactic acid with Alamine 336 in the presence of salts and lactose. Journal of Chemical Technology and Biotechnology 54, 1-6.

McCabe, W., Smith, J., Harriott, P., 1993. Unit Operation of Chemical Engineering. fifth ed. McGraw-Hill, New York.
Ruthven, D.M., 1984. Principles of Adsorption and Adsorption Processes. Wiley, New York.

Sato, K., Mijaki, Y., 1988. Japanese Patent No. 0263527.

Scholler, C., Chaudhuri, J., Pyle, D., 1993. Emulsion liquid membrane extraction of lactic acid from aqueous solutions and fermentation broth. Biotechnology and Bioengineering 42, 50-58.

Shimizu, K., Ye, K., Jin, S., 1996a. Cell recycle and broth reuse fermentation with cross-flow filtration and ion-exchange resin. Journal of Chemical Technology and Biotechnology 66, 1-4.

Shimizu, K., Ye, K., Jin, S., 1996b. Performance improvement of lactic acid fermentation by multistage extractive fermentation. Journal of Fermentation and Bioengineering 81 (3), 240-246.

Sun, Y., Li, Y.-L., Bai, S., Hu, Z.-D., 1999. Modeling and simulation of an in situ product removal process for lactic acid production in an airlift bioreactor. Industrial and Engineering Chemistry Research 38 (9), 3290-3295.

Suzuki, M., 1989. Adsorption Engineering. Elsevier, New York.

Treybal, R.E., 1981. Mass Transfer Operations. McGraw-Hill International Edition, third ed.

Tung, L., 1993. Recovery of carboxylic acid at $\mathrm{pH}$ greater than $\mathrm{pK}_{\mathrm{a}}$. Report No. LBL-34669, Lawrence Berkeley Laboratory, University of California, Berkeley.

Vonktaveesuk, P., Tonokawa, M., Ishizaki, A., 1994. Stimulation of the rate of L-lactate fermentation using Lactococcus lactis IO-1 by periodic Electrodialysis. Journal of Fermentation Technology 77, 508-512.

Wilke, C.R., Chang, P., 1970. A.I.Ch.E. J. 1, 264.

Yabannavar, V.M., Wang, C., 1991. Extractive fermentation for lactic acid production. Biotechnology and Bioengineering 37, 1095-1100. 